| JURNAL PETERNAKAN | VOLUME : 02 | NO : 02 | TAHUN 2018 | E-ISSN. 2599-1736|21

\title{
RESPON STRES AYAM BROILER YANG DISUPLEMENTASI NIRA AREN (Arenga pinnata Merr.) SELAMA FASE STARTER
}

\author{
Luky Wahyu Sipahutar \\ Program Studi Peternakan Fakultas Peternakan Universitas Muhammadiyah Tapanuli Selatan \\ e-mail : luky.wahyu@um-tapsel.ac.id
}

\begin{abstract}
Abstrak
Penelitian bertujuan mengetahui respon stres ayam broiler yang disuplementasi nira aren (Arenga pinnata Merr.) selama periode pemeliharaan fase starter. Sampel yang diamati sebanyak 100 ekor ayam broiler pada umur DOC sampai akhir fase starter (1-14 hari). Digunakan Rancangan Acak Lengkap yang terdiri dari 5 kelompok perlakuan (P) dan 4 ulang (U) dimana sampel ayam dibagi secara homogen. Suplementasi yang digunakan yaitu nira aren segar, dikonsentrasikan pada masing-masing kelompok perlakuan secara ad libitum yaitu 0\% (P1), 5\% (P2), 10\% (P3), 15\% (P4) dan 20\% (P5) dalam air minum v/v. Data yang damati berupa indikator stres dari respon fisiologi tubuh meliputi temperatur rektal, frekuensi pernafasan, dan frekuensi denyut jantung yang dianalisis menggunakan ANAVA, serta persentase mortalitas pada akhir pemeliharaan dianalisis secara deskriptif. Hasil penelitian menunjukkan suplementasi nira aren tidak berpengaruh nyata terhadap temperatur rektal $(\mathrm{P}>0,05)$ dan berpengaruh nyata terhadap frekuensi pernafasan dan frekuensi denyut jantung $(\mathrm{P}<0,05)$. Selama program pemeliharaan periode fase starter, tingkat mortalitas pada pemberian suplementasi nira aren berada di kisaran 5\% ( $\leq 5 \%)$ sedangkan pada kelompok kontrol tingkat mortalitas berada di $10 \%(>5 \%)$.
\end{abstract}

Kata kunci: stres, respon fisiologis, ayam broiler, nira aren, mortalitas

\section{PENDAHULUAN}

Program pemeliharaan ayam broiler semakin diminati oleh masyarakat karena dianggap sebagai komoditi yang menggembirakan. Namun, dalam masa awal pemeliharaan beberapa kendala sering dihadapi pada program pemeliharaan ayam broiler umumnya pada periode fase starter. Periode ini merupakan periode kritis dimana umur panen sampai pada tingkat peformans ayam banyak ditentukan pada fase starter (Fatmaningsih dkk., 2016). Kesalahan pada sistem pemeliharaan di Fase starter akan mempengaruhi fase berikutnya dan membutuhkan waktu yang lama dalam perbaikan kondisi peformans tubuh.

Berbeda dengan fase grower dan finisher, pada periode starter ayam broiler lebih cendrung mengalami stres sehingga lebih mudah terserang penyakit dan gangguan performans tubuh. Pemicu stres pada fase starter sering disebabkan oleh transportasi pada awal DOC masuk, hilangnya sistem thermolegulasi, kegagalan beradaptasi dengan lingkungan, dan daya konsumsi pakan akibat peristaltik usus. Stres yang terjadi akan memicu respon fisiologis yang abnormal pada tubuh. Respon fisiologis tersebut terbentuk akibat respon sistem syaraf otonom (SSO) tubuh ayam terhadap stresor, dan selanjutnya akan diperparah oleh respon hormonal jika tidak segera diatasi (Palupi, 2015). Respon fisiologis yang dihasilkan menjadi indikator penilaian stres yang sangat berpengaruh terhadap resiko kematian (mortalitas). Salah satu teknik yang digunakan dalam menilai respon fisiologis tersebut yaitu dengan mengukur temperatur rektal, frekuensi pernafasan, dan frekuensi denyut jantung.

Kondisi stres pada awal pemeliharaan, banyak berdampak terhadap tingginya mortalitas saat pemeliharaan berlangsung 
sehingga sangat merugikan secara finansial. Untuk mengatasi permasalahan tersebut, diperlukan treatmen dalam pemeliharaan periode starter. Salah satunya penggunaan suplementasi yang bertujuan menekan respon fisiologi tubuh terhadap stres. Nira aren (Arenga pinnata Merr.) dianggap sebagai salah satu bahan alam yang dapat bekerja menekan tingkat stres. Kandungan nira aren tersusun atas karbohidrat (glukosa dan fruktosa) $11,8 \%$, protein 0,28 , lemak 0,01 , Abu (kalsium dan posfor) $0,35 \%$, Vitamin C 0,01\%, dan air 89,23\% (Heryani, 2016).

Selain komposisi, pemilihan nira aren sebagai bahan suplementasi juga didasarkan pada penggunaan gula merah berbahan aren yang telah banyak digunakan dibidang peternakan. Salah satu khasiatnya mampu meningkatkat performans ayam (Aryanti dkk., 2013), dan mengurangi tingkat stres (Nangoy, 2012). Hal ini menjadi hipotesis penting dimana suplementasi yang dilakukan bukan dengan gula merah berbahan baku aren, melainkan penggunaan bahan dasarnya yaitu nira aren. Pemberian nira aren dimaksudkan untuk menyuplai sumber energi mudah diserap, memenuhi senyawa yang dibutuhkan oleh tubuh, dan mengembalikan kondisi fisiologis tubuh. Dengan kata lain, penelitaan ini bertujuan untuk melihat respon stres ayam broiler yang diberi treatmen suplementasi nira aren selama periode fase starter. Hasil penelitian ini diharapkan dapat memberikan informasi tentang manfaat penggunaan nira aren sebagai bahan suplementasi terhadap kondisi fisologis dan mortalitas ayam broiler pada fase starter sehingga akan memberikan gambaran pemanfaatan nira aren dalam menekan respon stres.

\section{METODE PENELITIAN}

Penelitian dilakukan di Mix Farming Experiencxce (MFE) Fakultas Peternakan
Universitas Muhammadiyah Tapanuli Selatan Padangsidimpuan. Metode penelitian disesuaikan dengan Rancangan Acak Lengkap (RAL) (Steel dan Torrie, 1995) dilakukan pada ayam broiler semenjak DOC sampai pada fase akhir periode starter (umur 1-14 hari) yang dipelihara secara intensif menggunakan kandang litter. Sebanyak 100 ekor DOC ayam broiler digunakan sebagai sampel uji dibagi secara homogen terdiri atas 5 kelompok perlakuan (P) dan 4 ulangan (U). Suplementasi yang digunakan yaitu nira aren segar, dikonsentrasikan pada masing-masing kelompok perlakuan secara ad libitum yaitu 0\% (P1), 5\% (P2), 10\% (P3), 15\% (P4) dan $20 \%$ (P5) dalam air minum v/v. Ayam diberi pakan yang telah diformulasi dalam bentuk ransum fase starter sebanyak $22 \mathrm{gr} / \mathrm{ekor}$ per hari. Pengambilan data respon fisiologis dilakuan sebanyak 2 kali yaitu pukul 09.00 dan $18.00 \pm 1$ jam setelah pemberian pakan dan air minum.

Pemeriksaan terhadap respon stres dilakukan dengan mengukur temperatur rektal, frekuensi nafas, dan frekuensi jantung ayam broiler selama fase starter. Pada periode akhir fase, dilakukan pengumpulan data mortalitas. Sebaran data respon stres dianalisis menggunakan uji sidik ragam ANAVA. Sedangkan data mortalitas dianalisis secara deskriptif.

\section{HASIL DAN PEMBAHASAN}

\section{Respon Fisiologis}

Respon stres yang diamati pada saat pemeliharaan dilakukan terhadap respon fisiologis tubuh diantaranya temperatur rektal frekuensi nafas, dan frekuensi jantung.

\section{Temperatur Rektal}

Temperatur atau suhu rektal diperoleh dengan cara memasukkan thermometer digital 
kedalam rektum ayam (Hartono dkk., 2002). Hasil penelitian pemberian suplementasi nira aren terhadap temperatur rektal ayam broiler disajikan pada Tabel 1.

Tabel 1. Rata-rata temperatur rektal ayam broiler fase starter 1-14 hari

\begin{tabular}{cccccc}
\hline Perlakuan & P1 & P2 & P3 & P4 & P5 \\
\hline $\begin{array}{c}\text { Rata-rata } \\
\left(\text { dalam }^{\circ} \mathrm{C}\right)\end{array}$ & 41.25 & 41.30 & 41.38 & 41.32 & 41.43 \\
\hline
\end{tabular}

Keterangan : Hasil analisis Anava $\mathrm{P}>0,05$

Hasil analisis statistik ANAVA menunjukkan pemberian nira aren pada ayam broiler fase starter tidak berpengaruh nyata terhadap temperatur rektal $(\mathrm{P}>0.05)$. Rataan temperatur terendah selama pemeliharaan adalah $41,25^{\circ} \mathrm{C}$ yaitu pada kelompok kontrol sedangkan yang tertinggi $41,43^{\circ} \mathrm{C}$ yaitu pada kelompok pemberian nira aren $20 \%$. Hasil ini menunjukkan terjadinya peningkatan temperatur rektal sejalan dengan besarnya dosis pemberian nira aren meskipun secara statistik tidak berpengaruh nyata. Grafik peningkatan temperatur rektal masing-masing kelompok perlakuan dapat dilihat pada Gambar 1.

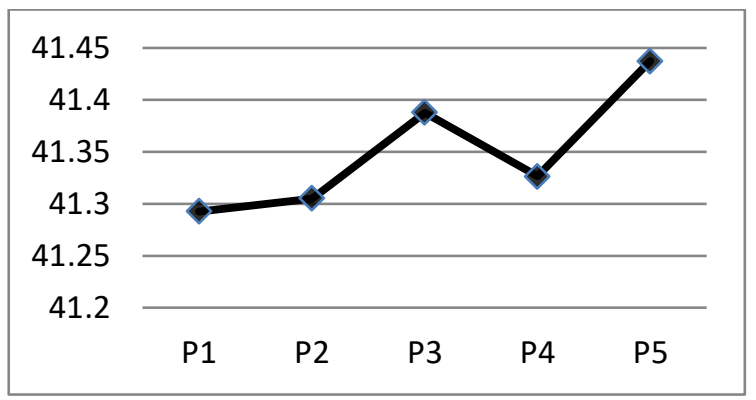

Gambar 1. Grafik peningkatan temperatur rektal ayam broiler fase starter yang disuplementasi nira aren

Berdasarkan pengamatan grafik dari Gambar 1 memperlihatkan bahwa temperatur rektal ayam broiler pada semua kelompok perlakuan yang diberi nira aren lebih tinggi dibandingkan kelompok kontrol. Dikategorikan temperatur rektal ayam broiler pada pemeliharaan fase ini cukup tinggi, namun masih dalam kisaran normal. Temperatur rektal ayam broiler normal yang dipelihara dalam kondisi letak kandang dengan ketinggian yang berbeda berkisar 40.06-41,19 ${ }^{\circ} \mathrm{C}$ (Qurniawan dkk., 2016). Sedangkan menurut Rasyaf (2008) temperatur ayam broiler berkisar $40-44^{\circ} \mathrm{C}$ dengan suhu lingkungan $25-29^{\circ} \mathrm{C}$ dan kelembapan 60$70 \%$. Siegel (1992) menjelaskan bahwa respon stres akibat berbagai dampak akan menunjukkan kenaikan temperatur tubuh mulai $42,2^{\circ} \mathrm{C}$.

Peningkatan temperatur tubuh ayam fase starter pada perlakuan ini disebabkan faktor keseimbangan fisiologis dimana peningkatan temperatur tubuh dilakukan untuk beradaptasi dengan lingkungan akibat hilangnya thermolegulasi dari induk serta menjaga haemostatik tubuh terhadap kondisi dan suhu lingkungan. Semakin rendah kondisi suhu lingkungan, maka ayam akan meningkatkan panas tubuh dengan cara berkumpul atau meningkatkan kerja organ. Hal ini senada dengan pendapat Freamen (1971) pada keadaan temperatur lingkungan $26^{\circ} \mathrm{C}$ ayam melakukan panting dan kenaikan suhu sebesar $0,1-04^{\circ} \mathrm{C}$.

Kenaikan temperatur rektal diduga juga dipengaruhi oleh laju fermentasi nira aren didalam tubuh. Nira aren dikenal memiliki tingkat fermentasi yang cepat. Fermentasi aren didalam tubuh dapat disebabkan oleh tidak tercernanya kandungan karbohidrat (sukrosa serta fruktosa) dari aren seiringa tingginya suplai nira yang masuk kedalam saluran cerna. Hal ini menyebabkan fermentasi oleh bakteri maupun jamur dan secara tidak langsung hasil fermentasi akan menghasilkan panas tubuh. Tingginya asupan karbohidrat yang diserap juga dapat menyebabkan kenaikan panas tubuh. Bila asupan karbohidrat yang diserap tubuh berlebih akan dirubah dalam bentuk lemak 
dan ikut berperan menghasilkan efek panas tubuh. Suplementasi nira aren pada penelitian ini dinilai berpengaruh meningkatkan panas tubuh ayam broiler fase starter dengan kenaikan temperatur rektal rata-rata sebasar $0,05-0,18^{\circ} \mathrm{C}$.

\section{Frekuensi Pernafasan}

Frekuensi pernafasan diukur dengan melakukan pengamatan pergerakan membuka dan menutupnya mulut selama satu menit (Hartono dkk., 2002). Hasil penelitian pemberian suplementasi nira aren terhadap frekuensi pernafasan pada ayam broiler disajikan pada Tabel 2.

Tabel 2. Rata-rata frekuensi pernafasa ayam broiler fase starter 1-14 hari

\begin{tabular}{|c|c|c|c|c|c|}
\hline Perlakuan & $\mathrm{P} 1$ & $\mathrm{P} 2$ & P3 & $\mathrm{P} 4$ & P5 \\
\hline $\begin{array}{c}\text { Rata-rata } \\
\text { (kali/menit } \\
\text { ) }\end{array}$ & $\begin{array}{c}28,8 \\
4\end{array}$ & $\begin{array}{c}28,7 \\
4\end{array}$ & $\begin{array}{c}28,7 \\
6\end{array}$ & $\begin{array}{c}28,1 \\
4\end{array}$ & $\begin{array}{c}28,2 \\
0\end{array}$ \\
\hline
\end{tabular}

Keterangan : Hasil analisis Anava $\mathrm{P}<0,05$

Dari Tabel 2 diatas terlihat kelompok perlakuan yang diberi suplementasi nira aren mampu menurunkan frekuensi pernafasan. Berdasarkan analisis ANAVA pemberian suplementasi nira aren dalam air minum berpengaruh secara nyata terhadap frekuensi pernapasan ayam broiler periode fase starter yang disuplemantasi nira aren $(\mathrm{P}<0,05)$. Pemberian nira aren dalam air minum dengan konsentrasi 5\%, 10\%, 15\%, dan 20\% masingmasing lebih kecil dibandingkan kelompok kontrol tanpa pemberian nira aren (0\%). Grafik penurunan frekuensi nafas ayam broiler pada masing-masing perlakuan dapat dilihat pada Gambar 2.

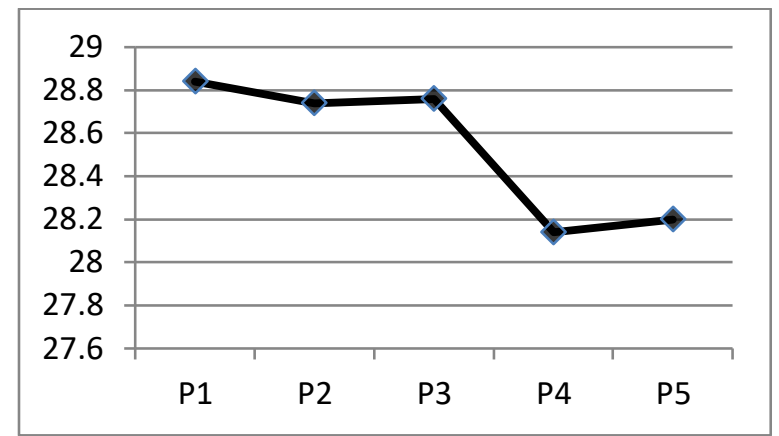

Gambar 2. Grafik penurunan frekuensi nafas ayam broiler fase starter yang disuplementasi nira aren

Berdasarkan pengamatan grafik dari Gambar 2 memperlihatkan terjadinya penurunan laju frekuensi pernafasan seiring dengan dosis pemberian suplementasi nira aren. Diketahui bahwa konsentrasi 15\% air nira menurunkan frekuensi nafas dengan tingkat terendah rata-rata sebesar 28,14 per menit dan meningkat sebesar 0,06 per menit pada besaran dosis $20 \%$. Rata-rata besaran frekuensi nafas pada penelitian ini tergolong tinggi namun masih berada pada kondisi normal. Menurut Abioja dkk., (2012), frekuensi nafas broiler normalnya sebanyak 20-30 kali per menit dan akan meningkat seiring laju suhu lingkungan dan kelembapan (Hapsari dkk., 2016) serta kepadatan populasi (Yunike dkk., 2014). Frekuensi pernafasan pada penelitian ini lebih tinggi dibandingkan penelitian yang dilakukan Haspari dkk., (2016) dimana frekuensi pernafasan menunjukkan lebih rendah dengan kisaran rata-rata sebesar 26,43-26,54 per menit pada ayam broiler umur 10 hari dengan sistem broding konvensional dan thermos. Tingginya rataan frekuensi pernafasan sejalan dengan parameter temperatur rektal yang diukur pada penelitian ini. Temperatur rektal berada dikisaran $41,25-41,43^{\circ} \mathrm{C}$, dimana tinginya temperatur tersebut mempengaruhi frekuensi pernafasan.

Imelda dkk., (2014) menjelaskan bahwa tingginya frekuensi pernafasan ayam diakibatkan karena adanya mekanisme 
thermoregulasi yang dilakukan tubuh ayam dalam rangka menyesuaikan diri dengan temperatur yang tinggi. Amstrong (1994) menambahkan bahwa ayam akan melakukan pelepasan panas tubuh melalui proses evaporasi yaitu pelepasan panas lewat mulut (panting) sehingga frekuensi pernafasan akan meningkat. Tingginya nilai frekuensi pernafasan pada ayam tanpa pemberian nira aren $(\mathrm{P} 1 / 0 \%)$, diduga disebabkan oleh respon keseimbangan tubuh terhadap lingkungan yang didapat semenjak DOC masuk akaibat transportasi, fluktuasi suhu kandang, pakan, dan dapat memicu terjadinya stres. Ayam broiler sebenarnya mampu untuk mentoleransi kodisi tersebut, namun pada fase starter kemampuan beradaptasi belum maksimal akibat belum sempurnanya sistem thermoregulasi tubuh. Setelah pemberian suplementasi, nira aren mampu menurunkan frekuensi pernafasan ayam broiler selama pemeliharaan fase starter rata-rata $0,26-0,34$ per menit.

\section{Frekuensi Denyut Jantung}

Frekuensi denyut jantung diukur mendengarkan sistole dan diastole selama satu menit menggunakan stetoscope yang ditempelkan dibagian dada kiri ayam (Hartono dkk., 2002). Hasil penelitian pemberian suplementasi nira aren terhadap frekuensi denyut jantung pada ayam broiler disajikan pada Tabel 3.

Tabel 3. Rata-rata frekuensi denyut jantung ayam broiler fase starter 1-14 hari

\begin{tabular}{cccccc}
\hline $\begin{array}{c}\text { Perlakua } \\
\mathrm{n}\end{array}$ & $\mathrm{P} 1$ & $\mathrm{P} 2$ & $\mathrm{P} 3$ & $\mathrm{P} 4$ & $\mathrm{P} 5$ \\
\hline $\begin{array}{c}\text { Rata- } \\
\text { rata }\end{array}$ & $\begin{array}{c}211,3 \\
7\end{array}$ & $\begin{array}{c}209,5 \\
3\end{array}$ & $\begin{array}{c}205,3 \\
7\end{array}$ & $\begin{array}{c}205,4 \\
2\end{array}$ & $\begin{array}{c}208,2 \\
8\end{array}$ \\
\hline (kali/menit) & & & & & \\
\hline
\end{tabular}

Keterangan : Hasil analisis Anava $\mathrm{P}<0,05$

Dari Tabel 3 diatas terlihat kelompok perlakuan yang diberi suplementasi nira aren menurunkan frekuensi denyut jantung ayam broiler pada fase starter. Berdasarkan hasil uji statistik menggunakan analisis ANAVA, pemberian suplementasi nira aren dalam air, minum berpengaruh secara nyata terhadap frekuensi denyut jantung ayam broiler periode fase starter yang disuplemantasi nira aren $(\mathrm{P}<0,05)$. Nilai rata-rata terendah pada pemberian suplementasi nira aren sebesar 205,37 per menit yaitu pemberian 10\% (P3). Grafik penurunan frekuensi denyut jantung ayam broiler pada masing-masing perlakuan dapat dilihat pada Gambar 3.

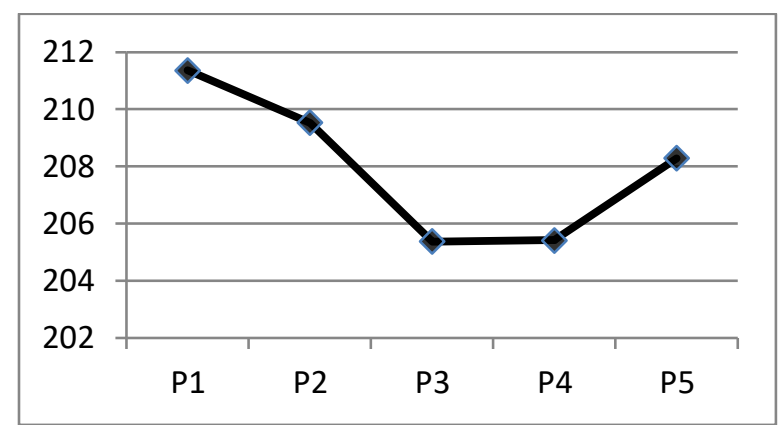

Gambar 3. Grafik penurunan frekuensi denyut jantung ayam broiler fase starter yang disuplementasi nira aren

Berdasarkan pengamatan grafik dari Gambar 3 memperlihatkan adanya penurunan frekuensi denyut jantung pada kelompok perlakuan yang diberi suplementasi nira aren (P2, P3, P4, P5) dibandingkan perlakuan kontrol (P1). Berdasarkan grafik tersebut juga terlihat adanya kenaikan denyut jantung pada dosis $15 \%(\mathrm{P} 4)$ dan $20 \%(\mathrm{P} 5)$ dibandingkan perlakuan $10 \%(\mathrm{P} 3)$. Hal ini menggambarkan bahwa adanya peningkatan frekuensi denyut jantung seiring dengan kenaikan dosis suplementasi nira aren melebihi $10 \%$. Nilai rataan pada tiap kelompok perlakuan menunjukkan frekuensi denyut jantung ayam broiler tergolong rendah dan masih dibawah kisaran normal. Menurut Frandson (1992), kisaran normal denyut jantung broiler yaitu 250-470 per menit. Penelitian yang dilakukan Haspari dkk., (2016) terhadap frekuensi 
denyut jantung ayam broiler 10 hari dengan perbedaan sistem brooding konvensional dan sistem brooding thermos sebesar 444,34-432 per menit. Perbedaan hasil ini dapat disebabkan oleh pengaruh suhu lingkungan pada saat pemeliharaan dimana suhu lingkungan mampu mempengaruhi frekuensi denyut jantung.

Menurut Zurriyati dan Dahono (2013) Frekuensi denyut jantung sangat dipengaruhi oleh faktor suhu lingkungan, pakan, dan aktifitas otot. Pada kondisi stres, fenomena peningkatan laju frekuensi denyut jantung dan frekuensi pernafasan merupakan konsekuensi mempertahankan keseimbangan tubuhnya, namun tidak selalu diikuti dengan peningkatan suhu tubuh ternak. McDowell (1974) menyatakan bahwa ekspresi ternak yang mengalami stres antara lain peningkatan suhu tubuh, frekuensi pernapasan dan denyut jantung.

Rendahnya frekuensi denyut jantung pada penelitian ini diduga berhubungan dengan metabolis energi dan rendahnya aktifitas ayam. Air nira memiliki kandungan energi yang mudah dicerna dan diserap oleh tubuh. Kandungan karbohidrat yang dubutuhkan dalam pembentukan energi pada air nira sebesar $11,8 \%$ dalam bentuk senyawa glukosa dan fruktosa yang bisa langsung diserap ke aliran darah selama pencernaan. Besarnya komposisi yang masuk juga akan menyebabkan rendahnya aktifitas ayam. Hal ini terlihat dari perilaku yang diamati selama penelitian menunjukkan dengan tingkat konsumsi air minum yang tinggi ayam terlihat lebih banyak berbaring dan diam. Selama periode pemeliharaan, pemberian suplementasi nira aren dalam air minum mampu menekan frekuensi denyut jantung ayam broiler fase starter dengan dosis ideal sebesar $10 \%$.

\section{Persentase Mortalitas}

Nilai persen mortalitas dihitung berdasarkan perbandingan ayam mati selama pemeliharaan dengan total populasi ayam awal masuk dan dikalikan dengan $100 \%$. Persentase mortalitas ayam broiler periode fase starter yang disuplementasi nira aren selama pemeliaharaan 1-14 hari disajikan pada Tabel 4.

Tabel 4. Persentase mortalitas ayam broiler pada fase starter 1-14 hari.

\begin{tabular}{cccccc}
\hline Perlakuan & P1 & P2 & P3 & P4 & P5 \\
\hline $\begin{array}{c}\text { Persentase } \\
(\%)\end{array}$ & 10 & 5 & 5 & 0 & 5 \\
\hline
\end{tabular}

Dari Tabel 3 diatas, selama pemeliharaan terjadi kematian ayam broiler pada kelompok perlakuan P1, P2, P3 dan P5. Sedangkan pada kelompok perlakuan P4 $(15 \%)$ tidak terjadi kematian sepanjang pemeliharaan 1-14 hari atau tingkat mortalitas adalah $0 \%$. Hasil pengamatan mortalitas ayam broiler selama fase starter dapat dilihat pada Gambar 4.

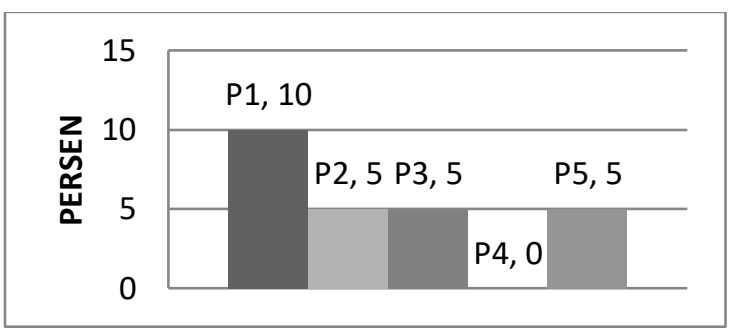

Gambar 4. Histogram persentase mortalitas selama pemeliharaan (1-14 hari)

Berdasarkan histogram pada Gambar 4, persentase tertinggi kematian ayam broiler terjadi pada kelompok tanpa suplementasi nira aren (P1) yaitu sebanyak 2 ekor atau tingkat mortalitas $10 \%$. Sedangkan pada kelompok yang disuplementasi nira aren, kematian ayam broiler selama pemeliharaan masing-masing sebanyak 1 ekor pada P2, P3, dan P5 atau tingkat mortalitas 5\% . Sedangkan pada P4 tidak terjadi kematian 0\%. Dapat 
dikatakan bahwa ayam broiler yang disuplementasi air nira aren pada periode pemeliharaan fase starter yaitu $\leq 5 \%$.

Persentase mortalitas dalam penelitian ini masih berada dikisaran ambang normal yang direkomendasikan yaitu 5\%. Menurut Clayton (1967), tingkat kematian ayam broiler sebesar 20-30\% dapat mempengaruhi biaya produksi sedangkan tingkat mortalitas 5\% tidak mempengaruhi biaya produksi. Mortalitas yang terjadi pada saat penelitian diduga disebabkan gangguan kondisi fisik ayam akibat transportasi dan toleransi yang rendah terhadap lingkungan. Pada fase starter, ayam masih sulit memulihkan kondisi fisik dan beradaptasi dengan lingkungan. Ayam broiler fase starter memerlukan penanganan khusus untuk menyeimbangkan kondisi tubuh serta suplai energi untuk memulihkan kondisi fisik akibat stres trasportasi dan lingkungan. Suplai asupan harus mengandung energi cukup untuk mendukung energi metabolisme dalam pertumbuhan dan memelihara kondisi fisik.

Penelitian yang dilakukan Aryanti dkk., (2013) terhadap ayam kampung yang diberi gula merah $1 \%$ dalam air minum mampu menekan mortalitas hingga 2,69\%. Ayam memerlukan asupan yang mengandung energi dalam jumlah besar. Tersedianya karbohidrat dalam nira aren bila dikonsumsi ayam, maka oleh tubuh akan dirubah menjadi energi potensial untuk kebutuhan thermoregulasi (keseimbangan panas tubuh), dan kebutuhan energi aktifitas. Kondisi ini selinier dengan parameter temperatur rektal, dimana suplementasi nira menyebabkan kenaikan temperatur rektal. Apabila kebutuhan karbohidrat telah terpenuhi, maka peran protein sebagai zat pembangun akan optimal dalam memelihara kondisi fisik (McLarent, 1981). Suplai asupan energi yang disuplementasikan dari nira aren pada ayam broiler mampu menurunkan angka mortalitas ayam sampai pada kondisi $\leq 5 \%$ dengan dosis ideal $15 \%$ dalam air minum.

\section{KESIMPULAN}

Berdasarkan hasil penelitian disimpulkan bahwa suplementasi nira aren pada ayam broiler selama fase starter dapat menekan respon stres. Dimana respon fisiologis pernapasan dan frekuensi jantung dapat diturunkan, namun tidak berpengaruh nyata terhadap temperatur rektal. Selama penelitian persentase mortalitas mencapai kondisi normal $(\leq 5 \%)$ pada pemberian suplementasi nira aren.

\section{DAFTAR PUSTAKA}

Abioja, M.O., K.B. Ogundimu, T.E. Akibo, K.E. Odukoya, O.O. Ajiboya, J.A. Abiona, T.J. Williams, E.O. Oke, dan O.O.Osinowo. 2012. Journal:Growth, Mineral Deposition, Responses of Broiler Chickens Offered Honey in Drinking Water During Hot-dry Season. Int. J. Zoo. pp:403-502.

Amstrong, D. V. 1994. Heat stress interaction with shade and cooling. Journal of Dairy Science. Vol.77. No.20 pp: 44-50.

Aryanti, F., M.B. Aji, dan N. Budiono. 2013. Pengaruh Pemberian Air Gula Merah terhadap Performans Ayam Kampung Pedaging. Jurnal Sain Veteriner. Vol.31 No. 2 hal: $156-165$.

Clayton, E. S. 1967. The Economic of thePoultry Industry. Longmans.Green and Co. Ltd. London

Fatmaningsih, R., Riyanti, dan Nova, K. 2016. Performa Ayam Pedaging pada Sistem Brooding Konvensional dan Thermos. Jurnal Ilmiah Peternakan Terpadu. Vol.4 No.3 hal: 222-229.

Frandson. 1992. Anatomi dan Fisiologi Ternak. Edisi IV. Gadjah Mada University Press, Yogyakarta. 
Freaman, B.M. 1971. Body Temprature and Thermoregulation. Physiology and Biochemistry of Domestic Fowl, Academic Press, New York, pp. 119-126.

Hartono, M., S. Suharyati, dan P. E. Santosa. 2002. Dasar Fisiologi Ternak. Buku Ajar Fakultas Pertanian Universitas Lampung, Bandar Lampung.

Hapsari, I.N., P.E. Santosa, dan Riyanti. 2016. Perbedaan Sistem Brooding Konvensional dan Sistem Brooding Thermos Terhadap Respon Fisiologis Broiler. Jurnal Ilmiah Peternakan Terpadu. Vol. 4 No.3 hal: $237-$ 243.

Heryani. H. 2016. Keutamaan Gula Aren dan Strategi Pengembangan Produk. Lambung Mangkurat University Pres, Banjarmasin.

Imelda, R., S. Suharyati, dan V. Wanniatie. 2014. Respon Fisiologis Ayam Petelur Fase Grower pada Kepadatan Kandang yang Berbeda. Jurnal Ilmiah Peternakan Terpadu.Vol.2 No.3. hal: 126-132.

McDowell, R. E. 1972. Improvement of Livestock Production in Warm Climate. W.H. Freemanand Co., San Frascisco. p.1-128.

McLarent, D. S. 1981. Nutrition and it's Disorder. Third Edition. Churchill Livingstone Edinburgh London Melbourne and New York, USA.

Nangoy, F.J. 2012. Kajian Penyusutan Berat Badan dan Peningkatan Suhu Tubuh Ayam Broiler Terimplementasi Kurkuma (Curcuma longa), Gula Aren (arenga pinata) Akibat Lama Transportasi. IJAS. Vol.2 No.3 hal: 119-122.

Palupi, R. 2015. Manajemen Mengatasi Heat Stress pada Ayam Broiler yang Dipelihara Dilahan Kering. Prosiding Seminar Nasional Lahan Suboptimal. Palembang 89 Oktober 2015. ISBN: 979-587-580-9.
Qurniawan, A., I.I. Arief, dan R. Afnan. 2016. Performans Produksi Ayam Pedaging pada Lingkungan Pemeliharaan dengan Ketinggian yang Berbeda di Sulawesi Selatan. Jurnal Veteriner. Vol.17 No.4 : hal: 622-633.

Rasyaf, M. 2008. Pengelolaan UsahaPeternakan Ayam Pedaging. Gramedia Pustaka Utama, Jakarta.

Siegel, H.S. 1995. Stress, Strains and Resistance. Brit Poult Sci 36. pp: 003-022.

Steel, R. G. D dan J. H. Torrie. 1995. Prinsip dan Prosedur Statistik Suatu Pendekatan Biometrik. Edisi 2, Cetakan 2, Alih Bahasa Bambang Sumantri. PT. Gramedia PustakaUtama, Jakarta.

Yunike, Y., S. Suharyati, dan K. Nova. 2014. Respon Fisiologis Ayam Jantan Tipe Medium di Kandang Panggung dengan Kepadatan Berbeda. Jurnal Ilmu Peternakan Terpadu. Vol.2 No.1 hal: 78-84.

Zurriyati, Y. dan Dahono. 2013. Respon Fisiologis dan Evaluasi Karkas Ayam Broiler Terhadap Suhu Pemeliharaan Dingin. Seminar Nasional Teknologi Peternakan dan Veteriner Tahun 2013. Balai Pengkajian Teknologi Pertanian Riau, Tanjung Pinang. 